\title{
Growth temperature regulates the induction of $\beta$-lactamase in Pseudomonas fluorescens through modulation of the outer membrane permeation of a $\beta$-lactam-inducing antibiotic
}

\author{
N. Orange \\ Tel: +33322915 66. Fax: +3332291546.
}

Laboratoire de

Microbiologie du Froid, Université de Rouen, Département de Biologie Appliquée de I'IUT de Rouen, 43 rue SaintGermain, 27000 Evreux, France
The psychrotrophic bacterium, Pseudomonas fluorescens strain MFO, is more sensitive to the $\beta$-lactam mezlocillin at a low growth temperature (i.e. $8^{\circ} \mathrm{C}$ ) than at a higher growth temperature $\left(28^{\circ} \mathrm{C}\right)$. An early effect of this antibiotic at all temperatures is bacterial filamentation, but this occurs later at $8{ }^{\circ} \mathrm{C}$ than at $28{ }^{\circ} \mathrm{C}$, which suggests a lower permeability of the cell envelopes to mezlocillin at low growth temperature. $\beta$-Lactamase production is later induced by mezlocillin, but the level of this induction also depends on the growth temperature, the overall induction being much less efficient at $8{ }^{\circ} \mathrm{C}$. It is hypothesized that the periplasmic concentration of the drug might be too low at $8^{\circ} \mathrm{C}$ to allow efficient $\beta$-lactamase induction; this hypothesis was confirmed by the demonstration that $\beta$-lactamase production is drastically enhanced in cells cultivated at $8^{\circ} \mathrm{C}$ permeabilized for $10 \mathrm{~min}$ by Na-EDTA. In addition, induction kinetic curves display a marked dependence upon growth temperature. A rapid saturation was evident when mezlocillin concentrations were increased at $8^{\circ} \mathrm{C}$; this was not seen at $28^{\circ} \mathrm{C}$ at up to $1000 \mu \mathrm{g}$ mezlocillin $\mathrm{ml}^{-1}$. The results are discussed in terms of two different routes of drug permeation, depending on the growth temperature.

Keywords: Pseudomonas fluorescens, $\beta$-lactamase induction, outer membrane permeability, growth temperature regulation, psychrophile

\section{INTRODUCTION}

Pseudomonas fluorescens, a Gram-negative bacterium, is surrounded by an outer membrane that acts as the first permeability barrier to the entrance of molecules into the cell. Numerous studies have shown that in all Gramnegative bacteria, transmembraneous protein channels, called porins, allow the penetration of hydrophilic solutes by passive diffusion, the rate of which depends, at least in the case of the major non-specific porins on the size and other physicochemical properties of the solute (Hancock, 1987; Nikaido, 1985). In contrast, hydrophobic molecules penetrate by diffusion through the lipid bilayer, although the presence of lipopolysaccharides (LPS) as a major constituent of the outer layer, strongly decreases this type of permeability (Hancock, 1985; Nikaido, 1985, 1990).

The permeability of Pseudomonas aeruginosa, a species belonging like $P$. fuorescens to the fluorescent pseudomonads, has been much studied (Hancock, 1987, 1991; Hancock et al., 1990). This species is highly impermeable (thus resistant) to most $\beta$-lactams, so the $\beta$-lactams that are able to penetrate have often been used to analyse the routes of molecule permeation in $P$. aeruginosa. This occurs mainly through non-specific porins, as shown with porin-deficient mutants (Nicas \& Hancock, 1983). The diffusion rate depends on hydrophobicity of the molecules (Nikaido et al., 1979; Bavoil et al., 1977). In addition, Hancock (1985) has shown by measurement of nitrocefin permeation that the permeability of the $P$. aeruginosa outer membrane is 12-fold lower than that of the Escherichia coli outer membrane and has demonstrated that only $100-400$ copies per cell of the non-specific porin $\mathrm{F}$ can form active functional channels. In contrast, $E$. coli is thought to have as many as 60000 functional channels per cell. The low permeability of the $P$. aeruginosa outer membrane was also confirmed by Yoshimura \& Nikaido (1985) with other permeation measurements.

P. fluorescens is a psychrotrophic bacterium. Over a range of growth temperatures $\left(0-35^{\circ} \mathrm{C}\right)$, the lipid composition of the membranes changes, i.e. the proportion of un- 
saturated fatty acids increases when the growth temperature decreases to maintain membrane fluidity (Bhakoo \& Herbert, 1980; Russell, 1990; Russell \& Fukunaga, 1990). However, it was not known whether these modifications influenced outer membrane permeability.

In a first attempt to answer this question, we have used the antibiotic mezlocillin. It is a monoanionic $\beta$-lactam from the ureidopenicillin group, with a large ramified chain that confers a low diffusion coefficient through the nonspecific porins (Yoshimura \& Nikaido, 1985). Yet, it is one of the very few $\beta$-lactams to which $P$. fuorescens is sensitive.

It is shown here that mezlocillin penetration into $P$. fluorescens strain MFO depends on the growth temperature, and that this is most likely the cause of the growthtemperature-dependence of induction rates of a periplasmic $\beta$-lactamase.

\section{METHODS}

Bacterial strain and growth conditions. Pseudomonas fuoresiens strain MFO (Gügi et al., 1991) was grown in citrate mineral salts medium containing $\left(\mathrm{g} \mathrm{l}^{-1}\right)$ : trisodium citrate, $3 ; \mathrm{K}_{2} \mathrm{HPO}_{4}, 10 \cdot 5$; $\left(\mathrm{NH}_{4}\right)_{2} \mathrm{SO}_{4}, 1.2 ; \mathrm{MgSO}_{4}, 0.4 ; \mathrm{CaCl}_{2}, 0.15 ; \mathrm{pH} \mathrm{6.8}$. When required, the $\beta$-lactam mezlocillin kindly provided by BayerPharma (France) was added to the culture medium at various concentrations $\left(50-1000 \mu \mathrm{g} \mathrm{ml}^{-1}\right)$. Cell densities were determined by measuring $\mathrm{OD}_{580}$ on a Spectronic 601 spectrophotometer $\left(1 \mathrm{OD}_{580}\right.$ unit $=0.65 \mathrm{mg}$ cell dry $\left.\mathrm{wt} \mathrm{ml}^{-1}\right)$.

Minimum inhibitory concentration (MIC). MIC was determined following Blechschmidt et al. (1989) in citrate mineral salts medium containing different concentrations of mezlocillin. The cultures were inoculated at $10^{5}$ cells $\mathrm{ml}^{-1}$ and incubated at the chosen temperatures. The MIC was defined as the lowest concentration of the antibiotic that inhibited visible growth after approximately 12 generations for each growth temperature.

$\boldsymbol{\beta}$-Lactamase assays. Exponentially growing cells were centrifuged for $5 \mathrm{~min}$ at $800 \mathrm{~g}$. The cell pellets were resuspended in the same volume of phosphate buffered saline (PBS) containing $\left(\mathrm{g} \mathrm{l}^{-1}\right): \mathrm{NaCl}, 8 ; \mathrm{KCl}, 0 \cdot 2 ; \mathrm{Na}_{2} \mathrm{HPO}_{4}, 1 \cdot 74 ; \mathrm{KH}_{2} \mathrm{PO}_{4}, 8$. Toluene $\left(15 \mu \mathrm{ml}^{-1}\right)$ was added and the mixture strongly agitated for $1 \mathrm{~min}$, then centrifuged for $5 \mathrm{~min}$ at $800 \mathrm{~g}$. The aqueous phase was used for $\beta$-lactamase determination. Ten microliters of the extract were added to a mixture, pre-heated at $30^{\circ} \mathrm{C}$, containing $300 \mu \mathrm{l}$ starch iodine reagent, $300 \mu \mathrm{l}$ freshly prepared $10^{-4} \mathrm{M}$ ampicillin (as substrate) and $390 \mu \mathrm{l} 0.1 \mathrm{M}$ sodium phosphate buffer, $\mathrm{pH} 7 \cdot 2$. The iodometric method for $\beta$-lactamase assay is based on a spectrophotometric measurement (at $540 \mathrm{~nm}$ ) of the amount of a complex formed between the product of the enzymic reaction (ampicilloic acid) and a starch-iodine derivative. The rate of decolorization of starch-iodine after addition of the extract, gives an estimate of enzyme activity. The results were expressed in activity units (U). One unit of $\beta$ lactamase is defined as the amount of enzyme that hydrolyses ampicillin at the rate of $1 \mu \mathrm{g} \mathrm{\textrm {min } ^ { - 1 }}$ (Sykes \& Nordström, 1972).

Measurement of cell length. Cell cultures $(10 \mu \mathrm{l})$ were placed on dry agar on the surface of a slide to block bacterial mobility. The sample was overlaid with a cover slip sealed with paraffin to prevent evaporation of the medium. Photographs were made of areas of attached cells (Pfennig \& Wagener, 1986) with an Olympus BM2 microscope at 1000 times magnification.
Cell treatment by Na-EDTA. Cell treatment by $\mathrm{Na}$-EDTA was performed by addition of $3.57 \mathrm{mM} \mathrm{Na-EDTA}$ to the culture growing at $8^{\circ} \mathrm{C}$ and at $17.5{ }^{\circ} \mathrm{C}$. This amount was calculated so that $\mathrm{Na}-\mathrm{ED}$ TA remained in excess once the divalent salts of the medium were chelated; this concentration has been used, for instance, to allow lysozyme penetration for outer membrane solubilization experiments (Mizuno \& Kageyama, 1978). After $10 \mathrm{~min}$ of incubation, $0.41 \mathrm{mM} \mathrm{MgSO}_{4}$ and $0.27 \mathrm{mM} \mathrm{CaCl}_{2}$ were added to the cultures to chelate $\mathrm{Na}$-EDTA (the same volume of medium being added to the controls).

\section{RESULTS}

\section{Effect of mezlocillin on the growth of $P$. fluorescens MFO in relation to temperature}

The behaviour of $P$. fluorescens was studied at $28,17 \cdot 5$ and $8{ }^{\circ} \mathrm{C}$. The optimal growth temperature is $28^{\circ} \mathrm{C}$ and $17.5^{\circ} \mathrm{C}$ is an intermediate temperature, which seemed critical for the production of several extracellular or periplasmic enzymes (Gügi et al., 1991; Mérieau et al., 1993; Hellio et al., 1993). A temperature of $8{ }^{\circ} \mathrm{C}$ is higher than the minimal growth temperature of this psychrotrophic bacterium $\left(0^{\circ} \mathrm{C}\right)$, giving growth rates amenable to experimentation. However, this temperature, being lower than the minimal growth temperature of most mesophilic species, is representative of psychrotrophic physiology.

The susceptibility of $P$. fuorescens to mezlocillin in relation to growth temperature appeared different according to the method used to investigate the behaviour of this strain. The MIC was $350 \mu \mathrm{g} \mathrm{ml}^{-1}$ for cells cultivated at $17.5^{\circ} \mathrm{C}$ and $28^{\circ} \mathrm{C}$, but lower $\left(150 \mu \mathrm{g} \mathrm{ml}^{-1}\right)$ when the growth temperature was decreased to $8^{\circ} \mathrm{C}$ (results not

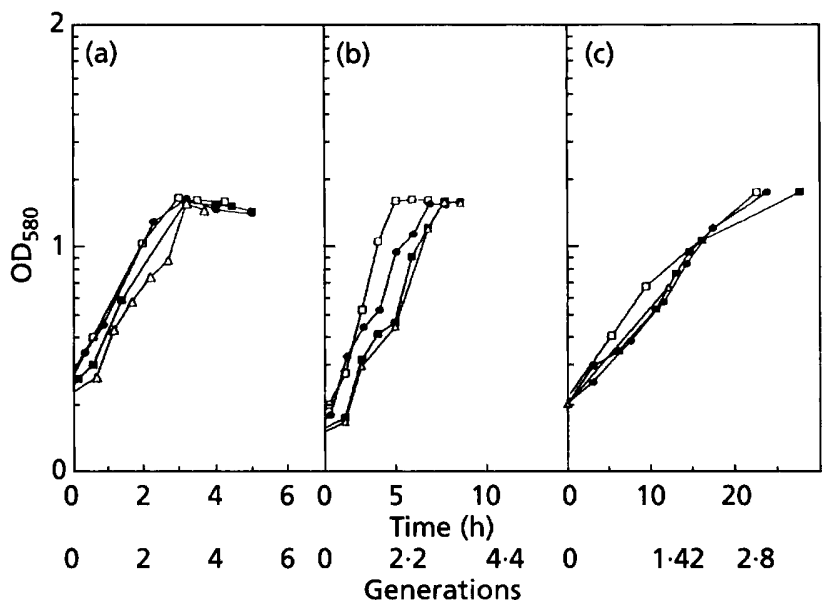

Fig. 1. P. fluorescens was grown at $28^{\circ} \mathrm{C}$ (a), $17 \cdot 5^{\circ} \mathrm{C}$ (b) and $8{ }^{\circ} \mathrm{C}$ (c). The following concentrations of mezlocillin $\left(\mu \mathrm{g} \mathrm{ml}^{-1}\right)$ were added to the medium when $\mathrm{OD}_{580}$ reached 0.2-0.3: 0 (control; $\square), 50(\triangle), 350(\triangle)$ and $750(\square)$. Antibiotic was added at time $=0$. For each culture, growth was expressed as a function of time in either $h$ or number of generations. The same results were obtained when mezlocillin was added at $O_{580}=0.04$ (data not shown). Individual points represent the mean of three measurements differing by less than $10 \%$ of the mean. 


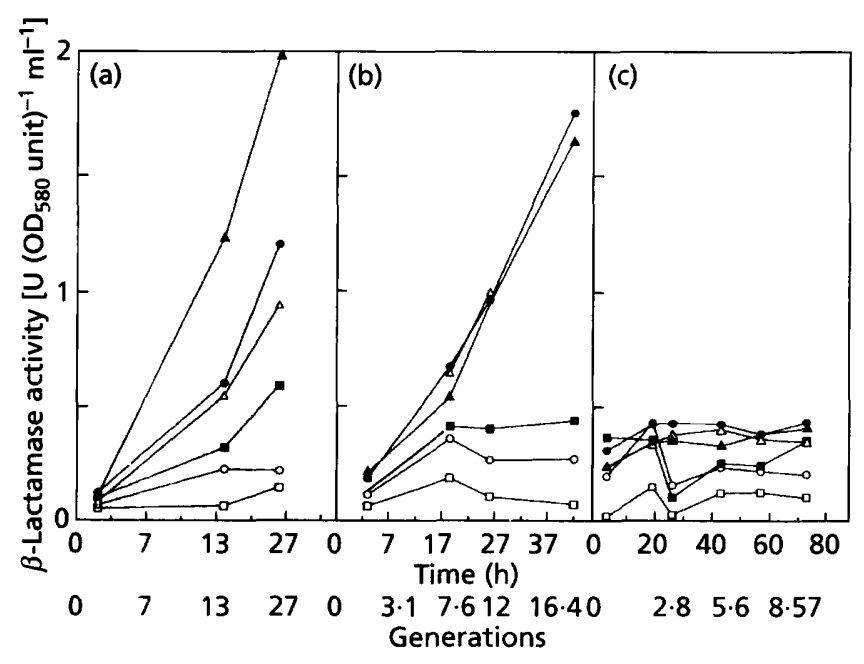

Fig. 2. $\beta$-Lactamase activities were assayed after addition of different concentrations of mezlocillin to cell cultures growing at $28^{\circ} \mathrm{C}(\mathrm{a}), 17.5^{\circ} \mathrm{C}$ (b) and $8{ }^{\circ} \mathrm{C}$ (c). The $\beta$-lactamase activities were expressed as a function of time in either $h$ or number of generations of exponentially growing cells, at the corresponding temperature. The following concentrations of antibiotic $\left(\mu \mathrm{g} \mathrm{ml}^{-1}\right)$ were added: 0 (control; $\square$ ), $250(0), 350$ $(\square), 550(\triangle), 750(\Theta)$ and $1000(\Delta)$. Results are the mean of three experiments differing by less than $10 \%$ of the mean. Antibiotic was added (time $=0$ ) when the cultures had reached $O D_{580}=0.2-0.3$. shown). In contrast, the growth yield was not affected up to $750 \mu \mathrm{g} \mathrm{ml}^{-1}$ at $28^{\circ} \mathrm{C}$ or $17.5{ }^{\circ} \mathrm{C}$ when mezlocillin was added to growing cultures at rather high cell densities $\left(\mathrm{OD}_{580} 0.04\right.$ and $0 \cdot 3$, i.e. $10^{7}$ and $10^{8}$ cells $\mathrm{ml}^{-1}$, respectively). The only detectable effect of the antibiotic at these cell densities was a slight decrease (less than $5 \%$ ) in growth rate at all three temperatures (Fig. 1). A cell density effect of this type is generally attributed to detoxification of the medium by periplasmic $\beta$-lactamases.

\section{$\beta$-Lactamase production at the different growth temperatures}

$\beta$-Lactamase was assayed with cells cultivated at the three temperatures and treated with different concentrations of mezlocillin when the cultures reached an $\mathrm{OD}_{580}$ of about $0 \cdot 3$ (Fig. 2). Constitutive activity was barely detectable in the control at the three temperatures. Enzyme induction was observed in all cases, although with quite different kinetics depending on the temperature. At $28{ }^{\circ} \mathrm{C}$ (Figs $2 \mathrm{a}$ and $1 \mathrm{a}$ ), induction was roughly proportional to antibiotic concentration from 250 to $1000 \mu \mathrm{g} \mathrm{ml}^{-1}$. Enzyme concentration kept increasing throughout the stationary phase.

At $8{ }^{\circ} \mathrm{C}$ (Fig. 2c) the level of induction was not dependent on antibiotic concentration in the range used and the increase of activity above the non-induced level was poor.

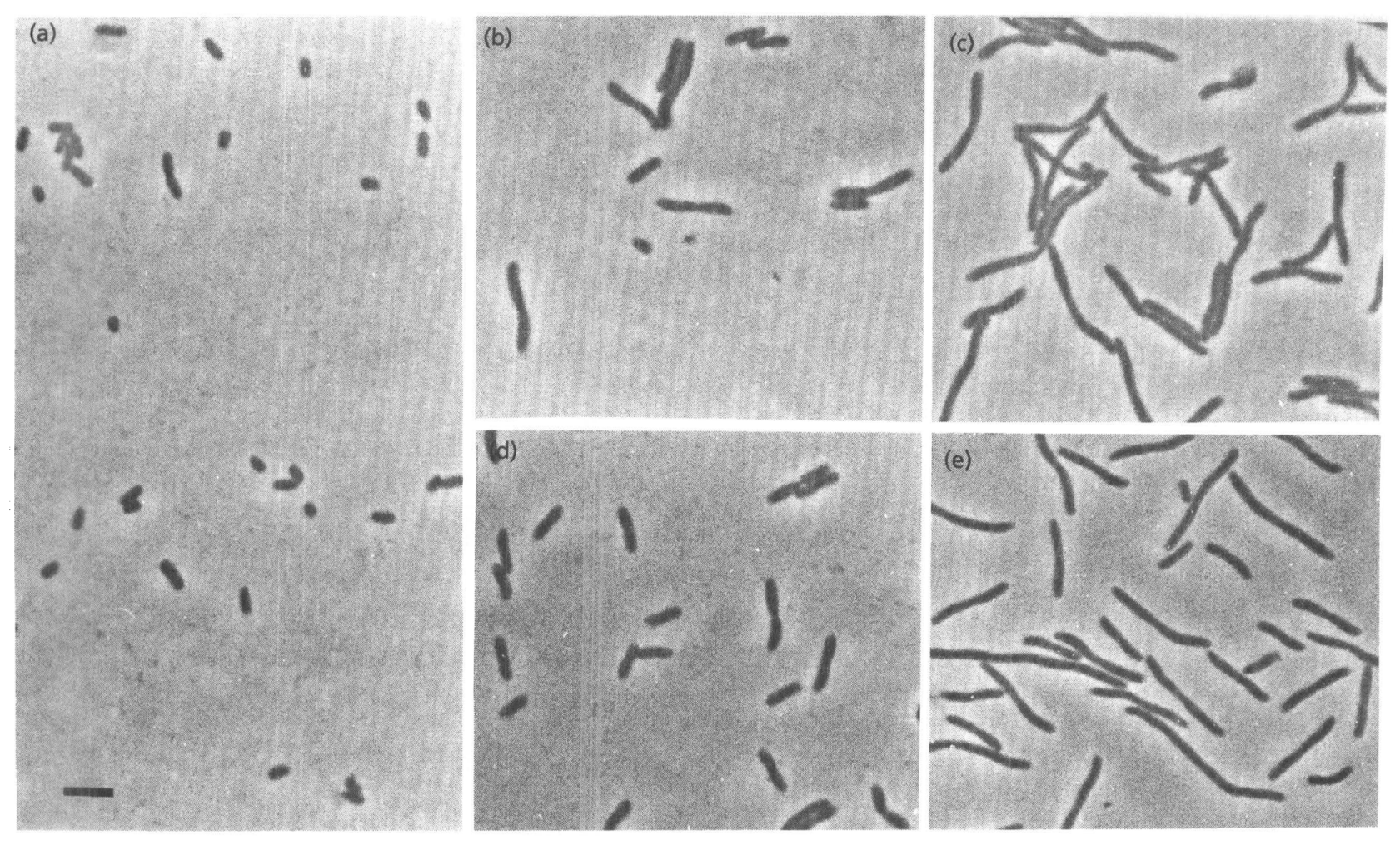

Fig. 3. Appearance of $P$. fluorescens cells upon mezlocillin addition under different conditions. (a) Culture at $28^{\circ} \mathrm{C}$ without mezlocillin. The same appearance of cells was obtained at $8{ }^{\circ} \mathrm{C}$. (b) Culture grown at $28^{\circ} \mathrm{C}$ with $350 \mu \mathrm{g}$ mezlocillin ml-1 for 90 min (corresponding to 1.5 generations). (c) Culture grown at $28^{\circ} \mathrm{C}$ with $350 \mu \mathrm{g} \mathrm{mezlocillin} \mathrm{ml} \mathrm{m}^{-1}$ for $3 \mathrm{~h}$ (corresponding to 3 generations). (d) Culture grown at $8^{\circ} \mathrm{C}$ with $350 \mu \mathrm{g}$ mezlocillin $\mathrm{ml}^{-1}$ for $7 \mathrm{~h} 15 \mathrm{~min}$ (corresponding to 1 generation). (e) Culture grown at $8^{\circ} \mathrm{C}$ with $350 \mu \mathrm{g}$ mezlocillin $\mathrm{ml}^{-1}$ for $22 \mathrm{~h}$ (corresponding to 3 generations). Bar, $5 \mu \mathrm{m}$. 


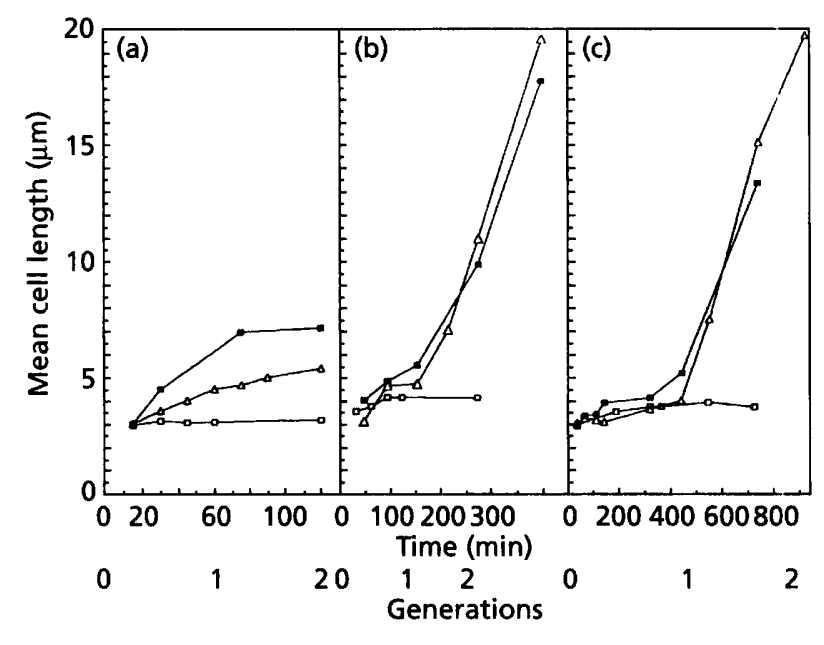

Fig. 4. The mean of about 100 cell lengths $( \pm 0 \cdot 15 \mu \mathrm{m})$ was compared from photographs taken of cell cultures at $28^{\circ} \mathrm{C}(\mathrm{a})$, $17.5^{\circ} \mathrm{C}(\mathrm{b})$ and $8{ }^{\circ} \mathrm{C}(\mathrm{c})$ after addition of two concentrations of mezlocillin $\left(\mu \mathrm{g} \mathrm{ml}^{-1}\right)$ under the conditions described in the legend to Fig. 2: 0 (control; $\square$ ), $50(\triangle)$ and $350(\square)$. Individual points represented the mean of two independent experiments. The length of cells is expressed as a function of time or as a function of the number of generations obtained at each growth temperature. Antibiotic was added at time $=0$.

Curiously, at $17.5^{\circ} \mathrm{C}$, the behaviour was not similar to that at $28^{\circ} \mathrm{C}$, as one would speculate from the identity of the MIC values obtained at these temperatures, but was intermediate between those observed at $28^{\circ} \mathrm{C}$ and $8{ }^{\circ} \mathrm{C}$ : up to $350 \mu \mathrm{g}$ mezlocillin $\mathrm{ml}^{-1}, \beta$-lactamase activity was poorly induced, did not increase significantly throughout the stationary phase and did not display a dose effect. At higher antibiotic concentrations, activity increased continuously throughout the stationary phase up to levels similar to those obtained at $28^{\circ} \mathrm{C}$, although in this concentration range $\left(550-1000 \mu \mathrm{g} \mathrm{ml}^{-1}\right)$ no difference was observed depending on antibiotic concentration. However, when the $\beta$-lactamase activities obtained after 10 generations, for instance, were considered, they were always slightly higher at $17.5^{\circ} \mathrm{C}$, which might be of significance, since the optimal temperature for the production of several extracellular and periplasmic enzymes has been found to be precisely $17 \cdot 5^{\circ} \mathrm{C}$ (Gügi et al., 1991; Mérieau et al., 1993; Hellio et al., 1993).

The induction kinetics, in all cases, did not parallel cell growth, suggesting that the difference in sensitivity to the antibiotic at various temperatures comes from another cause.

\section{Effect of mezlocillin on cellular filamentation}

Microscopic examination of mezlocillin-treated cultures showed the appearance of filaments (Fig. 3). Change in cell size was followed in cultures growing at the three temperatures with different concentrations of mezlocillin added at $\mathrm{OD}_{580}=0.3$ (Fig. 4). Results obtained at $8{ }^{\circ} \mathrm{C}$ and $17.5^{\circ} \mathrm{C}$ were similar, but at $8{ }^{\circ} \mathrm{C}$, the filamentation process started later (after one generation of cells). At these temperatures, and mainly at $8^{\circ} \mathrm{C}$, very long filaments were obtained up to six times the length of the individual cells. At $28^{\circ} \mathrm{C}$, the increase in cell size was extremely rapid: after $30 \mathrm{~min}$, i.e. less than one generation than twofold increase in size was observed with $350 \mu \mathrm{g}$ mezlocillin $\mathrm{ml}^{-\mathbf{1}}$. At this temperature, cell cultures were heterogeneous. Even after 10 generations, the filaments were shorter than those observed at $8^{\circ} \mathrm{C}$. At all three growth temperatures, the filaments kept their mobility.

Thus, filamentation appears to be an early effect of the antibiotic prior to $\beta$-lactamase accumulation and the

Table 1. $\beta$-Lactamase activities assayed at $8^{\circ} \mathrm{C}$ and at $17.5^{\circ} \mathrm{C}$ as a function of time in Na-EDTA-permeabilized and -nonpermeabilized cell cultures after addition of the antibiotic at $O D_{580}=0.3$

The treatments with mezlocillin are noted $(+)$ and correspond to the addition of $750 \mu \mathrm{g}$ mezlocillin $\mathrm{ml}^{-1}$ (at $8{ }^{\circ} \mathrm{C}$ ) and $350 \mu \mathrm{g} \mathrm{mezlocillin}$ $\mathrm{ml}^{-1}$ (at $17.5^{\circ} \mathrm{C}$ ), respectively. Cell permeabilization (noted + ) was accomplished by a 10 min treatment with $3.65 \mathrm{mM} \mathrm{Na-EDTA}$ in presence of mezlocillin at the two concentrations described above with regard to growth temperature. The Na-EDTA effect was then neutralized by $0.41 \mathrm{mM} \mathrm{MgSO}_{4}$ and $0.27 \mathrm{mM} \mathrm{CaCl}_{2}$ added at the same time to each culture. In controls for permeabilization with $\mathrm{Na}$ EDTA (noted -), Na-EDTA and salts (at the same concentrations as those previously described) were mixed and added to cell cultures at the same time as mezlocillin.

\begin{tabular}{|c|c|c|c|c|c|c|c|c|}
\hline \multirow{3}{*}{$\begin{array}{c}\text { Time } \\
\text { after } \\
\text { addition } \\
\text { of } \\
\text { mezlocillin (h) }\end{array}$} & \multicolumn{4}{|c|}{$\begin{array}{c}\beta \text {-Lactamase activity at } 8^{\circ} \mathrm{C} \\
{\left[\mathrm{U}\left(\mathrm{OD}_{580} \text { unit }^{-1} \mathrm{ml}^{-1}\right]\right.}\end{array}$} & \multicolumn{4}{|c|}{$\begin{array}{c}\beta \text {-Lactamase activity at } 17.5^{\circ} \mathrm{C} \\
{\left[\mathrm{U}\left(\mathrm{OD}_{580} \text { unit }\right)^{-1} \mathrm{ml}^{-1}\right]}\end{array}$} \\
\hline & \multicolumn{2}{|c|}{$\begin{array}{l}\text { Treatment with } \\
\text { mezlocillin }\end{array}$} & \multicolumn{2}{|c|}{$\begin{array}{l}\text { Permeabilization with } \\
\text { Na-EDTA }\end{array}$} & \multicolumn{2}{|c|}{$\begin{array}{l}\text { Treatment with } \\
\text { mezlocillin }\end{array}$} & \multicolumn{2}{|c|}{$\begin{array}{c}\text { Permeabilization with } \\
\text { Na-EDTA }\end{array}$} \\
\hline & - & + & - & + & - & + & - & + \\
\hline 6 & $0 \cdot 25$ & $0 \cdot 29$ & $0 \cdot 32$ & 0.32 & $0 \cdot 27$ & $0 \cdot 28$ & $0 \cdot 31$ & 1.09 \\
\hline 9 & $0 \cdot 30$ & $0 \cdot 35$ & 0.36 & 0.94 & $0 \cdot 26$ & 0.50 & 0.49 & $1 \cdot 10$ \\
\hline 15 & 0.23 & 0.85 & 0.61 & $3 \cdot 40$ & $0 \cdot 20$ & $0 \cdot 47$ & 0.40 & $1 \cdot 10$ \\
\hline 19 & $0 \cdot 24$ & 0.55 & 0.58 & $4 \cdot 19$ & $0 \cdot 21$ & $0 \cdot 48$ & $0 \cdot 40$ & $1 \cdot 18$ \\
\hline
\end{tabular}


difference in the rapidity of occurrence of this process might reflect the difference in the permeability to the antibiotic. The level of induction of $\beta$-lactamase could then depend on this permeability, and thus might be another measure of it.

\section{Effect of outer membrane permeability on $\beta$ - lactamase induction}

The latter hypothesis suggests that the low level of induction of $\beta$-lactamase obtained at $8{ }^{\circ} \mathrm{C}$ and at least for the lower concentrations $\left(<550 \mu \mathrm{g} \mathrm{ml}^{-1}\right)$ at $17.5^{\circ} \mathrm{C}$, simply reflects the low amount of penetration of the inducer through the outer membrane. To test this hypothesis, cells growing at $8{ }^{\circ} \mathrm{C}$ or at $17.5{ }^{\circ} \mathrm{C}$ were treated with Na-EDTA to increase outer membrane permeability, using conditions that do not irreversibly alter cell physiology. As shown in Table $1, \beta$-lactamase activity increased slowly in antibiotic-treated cells at $8{ }^{\circ} \mathrm{C}$ between 9 and $15 \mathrm{~h}$ after the addition of mezlocillin. In contrast, a dramatic $\beta$-lactamase induction was observed in cells permeabilized with Na-EDTA and was about eightfold higher in permeabilized cells than in nonpermeabilized culture. In the cells permeabilized at $17.5^{\circ} \mathrm{C}$, the $\beta$-lactamase activity, induced with $350 \mu \mathrm{g}$ mezlocillin $\mathrm{ml}^{-1}$. was only about twofold that of the nonpermeabilized control. However, the level of $\beta$-lactamase obtained in these conditions was lower $(1 \cdot 18)$ than that observed at $8{ }^{\circ} \mathrm{C}$. Thus, the induction of $\beta$-lactamase appears only dependent on antibiotic concentration when the barrier of permeability is released.

When Na-EDTA and salts $\left(\mathrm{CaCl}_{2}\right.$ and $\left.\mathrm{MgSO}_{4}\right)$ were added at the same time as mezlocillin (permeabilized cells with Na-EDTA, noted - in Table 1), growth rate was unchanged, culture yield only slightly decreased and the $\beta$-lactamase activity was equal to that of the treated cells with mezlocillin with regard to growth temperature.

\section{DISCUSSION}

The results show that the psychrotrophic bacterium $P$. fluorescens MFO is more sensitive to the $\beta$-lactam mezlocillin at $8{ }^{\circ} \mathrm{C}$ than at higher growth temperatures. This sensitivity is related to a much lower level of inducibility of the $\beta$-lactamase at this temperature. However, the accumulation of $\beta$-lactamase persisted long after the addition of the antibiotic to the cultures. Yet all cells proved resistant to the antibiotic when cell density was high enough. This suggests that $\beta$-lactamase induction is not the only cause of resistance to the antibiotic. In addition, an early effect of the antibiotic is cell filamentation. This process depends on growth temperature and also starts much earlier in terms of generation times at $28{ }^{\circ} \mathrm{C}$ (less than one generation) than at $8{ }^{\circ} \mathrm{C}$.

Cell filamentation is known to be due to binding of the antibiotic to one of the penicillin binding proteins (PBPs) mainly involved in septation and located in the cytoplasmic membrane. Some $\beta$-lactams such as the ureidopenicillins, selectively bind to PBP3 (at the MIC) and appear specifically to inhibit synthesis of the murein laid down during septum formation. Penicillin molecules presumably bind to the active sites of the mureintranspeptidases, since it is an analogue of their substrates and acetylates these penicillin-sensitive enzymes, thereby inactivating them (Park, 1987). Cells are unable to divide under these conditions and filaments are formed, indicating that the elongation continues when septation is blocked.

The difference in the kinetics of filamentation with regard to growth temperature of $P$. fuorescens MFO must reflect differences in the time required for the antibiotic to cross the outer membrane and the periplasm. While diffusing through the periplasm, the $\beta$-lactam molecules may first be hydrolysed, mainly by the constitutive $\beta$-lactamases, before binding to PBP3, but the non-induced level is very low and similar at all growth temperatures. Thus, the results suggest that the cells are more permeable to $350 \mu \mathrm{g}$ mezlocillin $\mathrm{ml}^{-1}$ at $28^{\circ} \mathrm{C}$ than at $8^{\circ} \mathrm{C}$ and at $17.5^{\circ} \mathrm{C}$.

This may explain the kinetics of $\beta$-lactamase induction. At $8{ }^{\circ} \mathrm{C}$, poor permeability of the outer membrane would give rise to low periplasmic concentrations of mezlocillin. Thus a low level of $\beta$-lactamase induction appears presumably because the amount of the antibiotic accumulated in the periplasm is not sufficient to induce $\beta$ lactamase. It is however sufficient to prevent cell growth, provided enough time for accumulation is given. In these conditions, cells show a greater sensitivity towards the antibiotic. The fact that Na-EDTA treatment, causing disorganization of the outer cell membrane in cells grown at $8^{\circ} \mathrm{C}$, drastically increased the $\beta$-lactamase induction level, proves that this level reflects the concentration of antibiotic in the periplasm and is not related to an impediment of the induction mechanism at low temperature. This result is confirmed by the one obtained at $17.5{ }^{\circ} \mathrm{C}$ with the low antibiotic concentration, showing that the level of $\beta$-lactamase induction depends mainly on the antibiotic concentration in permeabilized cells, and not on the growth temperature.

The shape of the induction kinetic curve and the results obtained by Na-EDTA treatment suggest that this low permeability might result from a rapid saturation of the permeation route. In contrast, at $28^{\circ} \mathrm{C}$, high permeability enables increasing antibiotic concentrations to induce increasing levels of $\beta$-lactamases. The shape of the induction kinetic curve suggests a non-saturable permeation route for the antibiotic at the concentrations used.

The results obtained at $17.5^{\circ} \mathrm{C}$ suggest that both routes are present, the non-saturable one being mainly open when high external antibiotic concentrations are present. This hypothesis is consistent with the fact that the hydrophilic $\beta$-lactams are known to cross the outer membrane of Gram-negative bacteria mainly through the non-specific porin channels (Hancock, 1985; Nikaido, 1985), but also through the lipid bilayer according to their degree of hydrophobicity (Nikaido, 1985, 1990).

In addition, Yoshimura \& Nikaido (1985) showed that compounds with exceptionally bulky side chains such as 
mezlocillin have a much lower permeability rate than that expected from their hydrophobicity. These molecules may, at least partly, also follow the penetration route of hydrophobic molecules through the lipid bilayer (Nikaido, 1985, 1990). To increase the permeability to the antibiotic of the outer membrane lipid bilayer, the lipopolysaccharide (LPS) must be altered by a permeabilizer such as Na-EDTA (Nikaido \& Vaara, 1985; Vaara, 1990). A fraction of LPS is also suspected by Hancock (1985) to react with the non-specific porins and to determine the number of open functional channels. This author has demonstrated that $\mathrm{OprF}$ of $P$. aeruginosa is present in 100000-300000 copies per cell but only $100-400$ porins are active.

Nevertheless, from the results obtained with $P$. fuorescen: cultured at different growth temperatures, it can be speculated that at $28{ }^{\circ} \mathrm{C}$ the permeability of $P$. fuorescen: outer membrane to mezlocillin is essentially through the non-specific porins as it is with $P$. aeruginosa (Hancock, $1984,1985)$, whereas at $8{ }^{\circ} \mathrm{C}$ the porin may be inactive, and the change in the composition of the membranes, might increase the permeation of the antibiotic through the hydrophobic part of the lipid bilayer.

\section{ACKNOWLEDGEMENTS}

I thank Dr Guespin, Dr Gügi and Dr Molle for their useful discussions and suggestions, and Dr Smith for his help in English language.

\section{REFERENCES}

Bavoil, P., Nikaido, H. \& Von Meyenburg, K. (1977). Pleiotropic transport mutants of $E$. coli lack porin, a major outer membrane protein. Mol \& Gen Genet 158, 23-33.

Bhakoo, M. \& Herbert, R. A. (1980). Fatty acid and phospholipid composition of five psychrotrophic Pseudomonas spp. growth at different temperatures. Arch Microbiol 126, 51-55.

Bleschmidt, B., Borneleit, P., Emanouilidis, I., Lehman, W. \& Kleber, H. P. (1989). Extracellular location of $\beta$-lactamase produced by Acinetobacter calcoaceticus. Appl Microbiol Biotechnol 32, 85-89.

Gügi, B., Orange, N., Hellio, F., Burini, J. F., Guillou, C., Leriche, F. \& Guespin-Michel, J. (1991). Effect of growth temperature on several exported enzyme activities in the psychrotrophic bacteria Pseudomonas fuorescens. J Bacteriol 173, 3814-3820.

Hancock, R. W. E. (1984). Alterations in the outer membrane permeability. Annu Rev Microbiol 56, 395-411.

Hancock, R. W. E. (1985). Effect of antibiotics on Pseudomonas. The Pseudomonas aeruginosa outer membrane permeability barrier and how to overcome it. Antibiot Chemother 36, 95-102.

Hancock, R. W. E. (1987). Role of porins in outer membrane permeability. J Bacteriol 169, 929-933.
Hancock, R. W. E. (1991). Bacterial outer membranes: evolving concepts. Specific structures provide Gram-negative bacteria with several unique advantages. Amer Soc Microbiol News 57, 175-181.

Hancock, R. W. E., Siehnel, R. \& Martin, N. (1990). Outer membrane of Pseudomonas. Mol Microbiol 4, 1069-1075.

Hellio, F. C., Orange, N. \& Guespin-Michel, J. (1993). Temperature regulation of protease secretion by Pseudomonas fluorescens MFO. Res Microbiol 144, 617-626.

Mérieau, A., Gügi, B., Guespin-Michel, J. \& Orange, N. (1993). Temperature regulation of lipase secretion by Pseudomonas fluorescens. Appl Microbiol Biotechnol 39, 104-109.

Mizuno, T. \& Kageyama, M. (1978). Separation and characterization of the outer membrane of Pseudomonas aeruginosa. $J$ Biochem 84, 179-191.

Nicas, T. I. \& Hancock, R.E.W. (1983). Outer membrane permeability in Pseudomonas aeruginosa. Isolation of a porin protein $\mathrm{F}$ deficient mutant. J Bacteriol 153, 281-285.

Nikaido, H. (1985). Role of permeability barriers in resistance to $\beta$ lactam antibiotics. Pharmacol Ther 27, 197-231.

Nikaido, H. (1990). Permeability of the lipid domains of bacterial membranes. In Membrane Transport and Information Storage, pp. 165-190. Edited by R. C. Aloja, C. C. Curtain \& L. M. Gordon. New York: Alan R. Liss.

Nikaido, H. \& Vaara, M. (1985). Molecular basis of bacterial outer membrane permeability. Microbiol Rev 49, 1-32.

Nikaido, H., Sony, S. A., Shaltiel, L. \& Nurminen, M. (1979). Outer membrane of Salmonella. XIV. Reduced transmembrane diffusion rates in porin deficient mutants. Biochem Biophys Res Commun 76, 324-330.

Park, J. T. (1987). The murein sacculus. In Escherichia coli and Salmonella typhimurium: Cellular and Molecular Biology, pp. 23-30. Edited by F. C. Neidhardt, J. L. Ingraham, K. B. Low, B. Magasanik, M. Schaechter \& H. E. Umbarger. Washington, DC: American Society for Microbiology.

Pfennig, N. \& Wagener, S. (1986). An improved method of preparing wet mounts for photomicrographs of microorganisms. $J$ Microbiol Methods 4, 303-306.

Russell, N. J. (1990). Cold adaptation of microorganisms. Phil Trans R Soc Lond B 326, 595-611.

Russell, N. J. \& Fukunaga, N. (1990). A comparison of thermal adaptation of membrane lipids in psychrotrophilic and thermophilic bacteria. FEMS Microbiol Rev 75, 171-182.

Sykes, R. B. \& Nordström, K. (1972). Microiodometric determination of $\beta$-lactamase activity. Antimicrob Agents Chemother 1, 94-99.

Vaara, M. (1990). Agents that increase the permeability of the outer membrane. Microbiol Rev 56, 395-411.

Yoshimura, F. \& Nikaido, H. (1985). Diffusion of $\beta$-lactam antibiotics through the porin channel of Escherichia coli K-12. Antimicrob Agents Chemother 27, 87-92.

Received 31 January 1994; revised 21 April 1994; accepted 11 July 1994. 